\title{
Design of Emergency Medical Record Form Based on Hospital Accreditation Standard Version 2012 in Hospital " $X$ "
}

Atma Deharja*, Selvia Juwita Swari, Dyah Eriyaning Esti

*Corespondent Author: atma.deharja@gmail.com

*Medical Record Study Program, Health Department, State Polytechnic of Jember, Indonesia

\begin{tabular}{l}
\hline I N D E X I N G \\
\hline Keywords: \\
Design; \\
Emergency Form; \\
Hospital Accreditation; \\
Medical Record;
\end{tabular}

Kata Kunci:

Desain;

Formulir Gawat

Darurat;

Akreditasi Rumah sakit;

Rekam Medis;

\begin{abstract}
A B S T R A C T
Based on pre-survey in Balung General Hospital, showed that emergency form has not qualified with hospital accreditation standard (version 2012) for an early medic and nursing assessment. The aim of this research is to re-design emergency forms based on hospital accreditation standard (version 2012) in Balung General Hospital. This research is a qualitative study with observation, interview, and brainstorming. The result of this research is viewed from physical aspect of emergency form using white paper in size of A4 80 gram in portrait layout. Based on anatomy aspect, the form heading is to put the logo, the name and the full address of the instance, the introduction which should be appropriate with the aim of the form that is the early medic and nursing assessment. Based on the content aspect of the emergency form, the additional data consists of a kind of triage, the date of arrival and handling, painful scale, medicine allergic and fall down risk. Based on the nursing assessment form, it consists of patient's identity, primary survey, secondary survey, nursing diagnose, action plan, self nurse-act, nursing evaluation, further action, given tasks and nurse authentication. Hopefully, the researcher's suggestion related to the result of emergency form design can be applied in Balung General Hospital, Jember.
\end{abstract}

\begin{abstract}
Berdasarkan hasil survei awal di RSD Balung Jember, didapatkan informasi bahwa formulir gawat darurat yang ada belum memenuhi kebutuhan standar akreditasi rumah sakit versi 2012 untuk assessment awal medis dan assessment keperawatan sehingga informasi yang didapatkan tidak maksimal. Tujuan dari penelitian ini mendesain ulang formulir gawat darurat berdasarkan standar akreditasi rumah sakit versi 2012 di Rumah Sakit Daerah Balung Jember. Penelitian ini merupakan penelitian kualitatif dengan observasi, wawancara dan brainstorming. Hasil dari penelitian ini dilihat dari aspek fisik formulir gawat darurat menggunakan kertas warna putih dengan ukuran A4 80 gram berbentuk portrait. Dilihat dari aspek anatomi, heading formulir gawat darurat mencantumkan logo, nama instansi dan alamat lengkap dari instansi, introduction dibuat sesuai dengan tujuan formulir yaitu assessment awal medis dan assessment keperawatan. Dilihat dari aspek isi, formulir assessment awal medis data yang ditambahkan terdiri dari jenis triage, tanggal/ waktu kedatangan dan waktu penanganan, skala nyeri, alergi obat dan risiko jatuh. Dilihat dari aspek isi formulir assessment keperawatan terdiri atas data identitas pasien, survei primer, survei sekunder, diagnosis keperawatan, rencana tindakan, tindakan keperawatan mandiri, tindakan kolaborasi, evaluasi keperawatan dan otentikasi perawat. Saran dari peneliti hasil desain formulir gawat darurat diharapkan dapat diterapkan di RSD Balung Jember.
\end{abstract}

(C) 2017 JMMR. All rights reserved

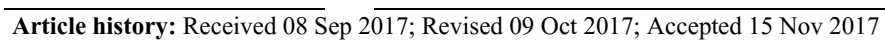

\section{INTRODUCTION}

According to the Law of the Republic of Indonesia Number 44, 2009, hospital is a private health service institution which provides inpatients, outpatients and emergency services. Established Hospitals are obliged to obtain hospital accreditation stipulated in the Regulation of the Minister of Health Number 56, 2014 on Hospital
Classification and Licensing to Extend Operational License and Hospital Class Changes. Based on the Regulation of the Minister of Health of the Republic of Indonesia Number 12, 2012, hospital accreditation is the recognition of the hospitals provided by independent accreditation institution appointed by the minister. After assessment, the hospital meets the applicable hospital service standards to improve the quality of hospital services on a continuous basis. ${ }^{1}$ To 
meet the demands of hospital accreditation in 2012, emergency medical record needs to be conducted in accordance with standar. ${ }^{2}$ The medication discrepancies can prolong hospital stays and, in the post discharge period, may lead to emergency department visits, hospital readmissions, and use of other health care resources. ${ }^{3}$

Balung Local Hospital (RSD) of Jember is a government-owned health service with type D located in Balung Sub-district Jember. This hospital is a referral hospital of a first-rate service in the southern part of Jember which provides inpatients, outpatients and emergency care services.

Based on the result of interviews with medical record officers in the Emergency Installation (IGD) no nursing assessment form and a standardized initial medical assessment have been implemented in contrast with inpatient care unit which has a medical assessment form, nursing assessment and nutrition assessment. developments in medical technology, innovations in health care delivery, changes in consumer needs and expectations. ${ }^{4}$

Whereas, the unit existing outpatient assessment services have been adapted to their respective specialties. However, the result in the patient receiving potentially to service of medical, inaccurate and treatment. ${ }^{5}$ Patients who enter the ER need a quick and an appropriate and standard help in providing emergency services in accordance with the competence and ability so that it can guarantee an emergency treatment with quick response time and proper handling. ${ }^{10}$

The available emergency form has not met the requirements of the 2012 hospital accreditation standard for the initial medical assessment including patient identity, triage type, documented medical history, psychological, falling patient risk, patient functional status, physical examination, pain scale and physician authentication while none Nursing assessment consists of anamnesis, history of disease, physical examination, nursing assessment, nursing diagnosis, nursing action, nurse authentication. It adopts the design of 2007 standard version, the emergency form has not been coherent and informative, the available emergency form is used 2 (two) different practitioners ie doctors and nurses with no monitoring and evaluation on the design of emergency forms and no charging guidelines.

The emergency room used by the IGD RSD Balung Jember consists of patient identity, anamnesis, physical examination, laboratory, diagnosis, follow-up and physician authentication to conclude that the available emergency form has not met the standard. It is therefore necessary to add some points to the initial medical assessment form consisting of triage type, patient psychological state, pain scale, drug allergy, functional status, fall risk, additional filling space in the history column to conform to the standard initial medical assessment form and nursing at IGD. The incompleteness of medical documentation or nursing in RSD Balung Jember will most likely cause discontinuity of patient information if the available assessment has not met the standard so that it will affect the quality of health service. Poorly designed forms may result in inadequate data collection, documentation becomes sluggish, faulty information, duplicate errors are made, and errors. ${ }^{8}$

The need for medical and nursing services is determined by the basis of preliminary medical assessments and recorded in clinical records. ${ }^{9}$ The initial medical and nursing assessment of emergency patients should be based on their needs and circumstances. The result of the assessment is to understand the need for medical services and nursing services so that care and treatment can begin.

Based on this background, the problem formulation of the research is "How to Re-Design Emergency Form Based on Accreditation Standard Hospital 2012 Version at Balung Local Hospital of Jember in 2016.

\section{RESEARCH METHOD}

This is a qualitative research conducted at Balung Hospital from June to October 2017. Data collection techniques were observation, interview and brainstorming. Observations were used to assess emergency forms comprising 3 (three) aspects i.e. physical aspects, aspects of anatomy as well as aspect of content. Interviews then are used to determine the users' needs of preliminary medical assessment form and nursing assessment prior to new form redesign. Interviews were conducted with 4 doctors, 4 nurses and 2 medical recorders. Brainstorming was then carried out to present the new form of design result.

Content analysis was deployed as data analysis techniques through observation, interview, and brainstorming associated with the standard theory and the design of the initial medical assessment form and nursing so that researchers can present findings in the form of initial medical assessment and nursing form IGD according to user requirements and standards so that the new form will likely to be more efficient and much easier to use. 


\section{RESULTS AND DISCUSSION}

Physical Aspects Identification (Display), Aspects of Anatomy (Attributes) and Contents Aspects of Old Form of Emergency

Identification is an attempt to review the process of making a good re-designed form, in accordance with user requirements and standards to improve work efficiency. In designing the form 3 points to ponder namely physical aspects, aspects of anatomy and aspects of content. ${ }^{11,13,16,28}$

\section{Physical Aspects}

Based on the observation, the ink used on the emergency form of RSD Balung Jember is black. Type of paper used legal with size $21.59 \mathrm{~cm}$ x $35.56 \mathrm{~cm}$ and weight 70 grams. According Riyaty Noor in Wardhani (2015), to design a form, the material of the form used should be considered, especially the one form stored or ignored. Materials used for the stored or skipped form are at least 80 grams of HVS. The paper is white. ${ }^{16,17,23}$ The form of emergency form of RSD Balung Jember is a portrait.

\section{Aspect of Anatomy}

The form head (headings) on the emergency form of RSD Balung Jember include logo and the name of the hospital institution "Balung Local Hospital", stating the address of the hospital institution "Jl. Rambipuji No. 19 Tel. 0336-621595, 623877 Balung-Jember 68161", stating the identity of the "Emergency Medical Record" form. The heading section of the Emergency form contains the identity of the hospital institution along with the logo, the address of the hospital institution, and the identity of the form. ${ }^{26,27}$ For the identification of emergency RSD Balung form is adapted to the type of form, namely the initial medical assessment form and the nursing assessment.

The introduction in the emergency form is represented by the title of the form "Emergency Medical Record" on the top left of the form. This introductory section explains the purpose of the form and sometimes the purpose is also indicated by the title. ${ }^{8}$

Instruction guidance in emergency form of RSD

Balung Jember have been available i.e. mark $\sqrt{ }$ on the need and circle one $+/-$ ( + if yes and - if not) are at the bottom and identity form RM.GD is on top right corner. Margins on RSD Baluran Jember emergency form with top size 1.3 $\mathrm{cm}$, left left $1.3 \mathrm{~cm}$, bottom border $4 \mathrm{~cm}$, right limit $1.2 \mathrm{~cm}$.
With irregular border size will affect the aesthetics of the form.

The typeface (letters) on the emergency form of RSD Balung Jember use 3 types of letters and sizes indicated as follows:

a) Times New Roman font on the head of the form (heading) "HOSPITAL BALUNG" with size $26 \mathrm{pt}$.

b) The type of arial letter in the address section "Jl. Rambipuji No. 19 "using 12 pt size, phone number" Tel. 0336-621595 / 623877 "using 12 pt size, on" RM.GD "form identity using $10 \mathrm{pt}$ size, title of" EMERGENCY MEDICAL EMERGENCY "form using 12 pt size, item" ANAMNESA "using size 14 $\mathrm{pt}$ and on item fill form with a size of $12 \mathrm{pt}$ starting from the item of the patient register number to the authentication item of the person in charge (doctor / nurse). Calibri letters on the patient's identity include registration number, RM number, name, sex, age and space / class. This is supported by Huffman5's theory that for a form it is best to use a few types and font sizes.

c) The Closing on the emergency form RSD Balung Jember already has room where the signature and the bright name of the doctor in charge of patient ${ }^{9}$.

\section{Aspect of Content}

Aspects of content in the design of a form include the division of data items, data clustering, sequence and filling mode. ${ }^{17,25,28,29}$ The data items contained in the RSD Jember emergency form meet the objectives of data collection including medical record number, name, gender, age, address, neighborhood, village, sub-district, district / city, introductory name, introductory address, introductory ID number, date and time of incident, place of incident, type of case consisting of: surgical, non surgical, trauma, non trauma, interna, child, obstacle, nerve, injury, date and in the hospital, transportation time comes, the triage officer, the date and the doctor checked.

The history items section on the RSD Baluran Jember emergency form include: major complaints, current disease history, disease history. Existing physical check items on the RSD Baluran Jember emergency form include vital signs, general examination (breathing, nutrition, skin, head, eyes, ears, nose, mouth, neck, thorax, abdomen, genetalia, extremity) anatomy, investigation, and examination of patients in a disaster state. Other items listed on the form of work diagnosis, therapy or action (type of action, start and end time), follow-up (consultation of specialist physician, repatriated for control, HCU / ICU / ward care, death, sent / 
referenced, transportation, basis) other notes, bright names and DPJP signatures.

Grouping of the RSD Balung emergency medical record form has several groups of data items such as hospital identity group, form identity group, social identity group, group triage IGD, anamnesis group, physical examination group (vital signs and general examination), investigation groups, patient examination groups in disaster situations, diagnostic and therapeutic/action groups, followup groups, cover groups.

The order in the emergency medical records form of RSD Balung Jember has been in accordance with the existing groupings. However, based on observations, what was listed on the form only the officer triage with no type of triage. The way to fill out emergency medical record form of RSD Balung Jember is manually handwritten by doctors and nurses IGD.

Identifying the standad of Initial Emergency Medical Assessment Form at Level III Hospital Baladhika Husada Jember

\section{Physical Aspects}

The medical assessment form used at Baladhika Husada Jember III level hospital uses black ink and white paper. Type and size of paper used is HVS 70 grams with size $21.59 \mathrm{~cm} \times 35.56 \mathrm{~cm}$. The paper is white.

\section{Aspect of Anatomy}

The anatomical aspect in the design of the form consists of the head of the form (heading), introduction, instructions, body forms (body) and cover (close).Head of form used on the initial emergency medical assessment form that is Hospital Level III Baladhika Husada Jl. PB. Sudirman No. 45 Tel. 0331 484674. Introduction used in accordance with the 2012 KARS accreditation standard is about emergency medical assessment. The instructions listed on the form are FORM: 01. The margins on the left and bottom margins are $2 \mathrm{~cm}$, the upper limit is $0.8 \mathrm{~cm}$, the right limit is $1.7 \mathrm{~cm}$. The typeface (type styles) uses calibri typeface. The cover section of the form lists the doctor's signature column.

\section{Aspect of Content}

Aspects of content in form design include the division of data items, data groupings, sequences and ways of charging. ${ }^{13}$ The division of items on the medical assessment form of hospital level III Baladhika Husada Jember hospital patient identification, triage consists of: case type; type triage; primary survey; the way patients come, assessment consists of: auto and allo anamnesis; check and return hours; psychological status; socioeconomic status and authentication of triage officers, major complaints, current patient history, past patient history, allergy history, awareness level, general state, weight, height of vital signs, pain scale, falling patient risk, functional status, secondary survey include: head; eye; neck; chest; stomach; motion device; diagrams of anatomy of the body, name of the nurse in charge of the patient, doctor's name, occupational diagnosis, reassessment, investigation, conclusion of improvement, stable, worsening, follow-up, condition of patient exit, follow-up instruction, medicine at home and follow-up care.

Data grouping on medical assessment form of hospital emergency level III Baladhika Husada Jember is what follows:
a) Hospital Group identity
b) Group identity form
c) Patient Identity Group
d) Triage group
e) Assessment group
f) Physical examination group
g) Secondary survey group
h) Handling groups
i) Investigation group
j) Group of conclusions
k) Follow-up group
1) Review group
m) Advanced group of instructions and home medications
n) Advanced care group
o) Cover form Group
Ordering data on the form was based on previous data groupings. The way to fill the form is manually handwritten by doctors on duty in the ER.

\section{Identifying Standard of Emergency Nursing Assessment Form at Level III Hospital Baladhika Husada Jember}

\section{Physical Aspect}

The nursing assessment form used at Baladhika Husada Jember III hospital does not vary dealing with the medical assessment form using black ink and white paper. Type and size of paper used is HVS 70 grams with size $21.59 \mathrm{~cm} \times 35.56 \mathrm{~cm}$. 


\section{Aspects of Anatomy}

The anatomical aspect in the design of the form consists of the head of the form (heading), introduction, instructions, body forms (body) and cover (close). The head of the form is made as in the head of the preliminary medical assessment form including the name of the hospital institution, the address of the staffs and the hospital telephone number.

Introduction used is in accordance with the 2012 KARS accreditation standard about emergency nursing assessment. The instruction instructions listed on the form are FORM FORM: $02 \mathrm{~A}$. The margins on the standard form are the left border of $2 \mathrm{~cm}$, the upper limit of $0.8 \mathrm{~cm}$, the right and the lower border of $1.6 \mathrm{~cm}$. The typeface (type styles) uses Calibri typeface. The closing section of the form lists the nurse's signature column that is responsible for the patient. ${ }^{22}$

\section{Aspects of Content}

The division of items listed on the nursing emergency assessment form of hospital III level Baladhika Husada Jember includes major complaints, disease history, primary survey (airway: free, gargling, wheezing, ronchi, stridor, snoring, incubated, breathing: spontaneous; tachipneu; dispneu mechanical ventilation, ventilator wear, respiratory, circulation: tension, CRT, skin color, hemorrhage, skin turgor, disability: response pupil light reflex and awareness level), secondary survey (anatomy diagram, pain, abrasion, lacerations, contusions, bite burns, puncturing, vulnus apertum, ptichiae, weight, height, pain scale), assessment, nursing diagnosis, nursing plans / actions, hours and evaluations, abundant tasks, authentication of duty, authentication of the nurse responsible for the patient.

Grouping of data on emergency nursing assessment form RS III Baladhika Husada includes:
a) Hospital Identity Group
b) Identity Group
c) Patient's social identity group
d) History Group
e) Primary survey group
f) Secondary survey group
g) Closing Form group

The sequence of the data on nursing emergency form of Hospital Level III Baladhika Husada Jember has been in accordance with the above data grouping. The way to fill out emergency nursing care forms is filled manually by the nurse responsible for the patient.

\section{Identifying Users' Needs Based on Physical, Anatomical and Content Aspects of Emergency Medical Initial Emergency Assessment Form}

Identification of need in early emergency medical assessment form RSD Balung Jember was implemented using interview technique to user that is doctor and medical recorder as designer of form.

\section{Physical Aspects}

Based on the results of interviews with the respondents, the desired material is white paper with a weight of 80 grams A4 size and black ink. ${ }^{1,7,17}$

\section{Aspects of Anatomy}

The head of the form (heading) desired in accordance with the standard hospital consists of logo, name of agency, complete address, phone, faximili and placed on the top left. ${ }^{2,15,20}$

The introductory section is indicated by the title of the form, the title of the desired form for the new form is an initial emergency medical assessment. The space used for the design of the new form is 1.15 with the arial font so that there is no bias between 1 and $\mathrm{L}$ when using the new times. The closing section must exist for physician authentication.

\section{Aspects of Content}

Based on the results of interviews, most doctors stated that at least initial medical emergency assessment form should produce patient identity information, triage type, primary survey (using $\mathrm{ABCDE}$ method) and secondary surveys include: history, medical history, physical examination, assessment (assessment of pain and fall risk), and physician authentication.

According to hospital accreditation standards in 2012 the initial emergency medical assessment form contains information about the patient's identity, medical history, physical examination, arrival time, conclusion on termination of treatment, condition of patient upon discharge, follow-up instruction, DPJP authentication and other assessment related.

Based on that fact, the content should be on the new preliminary medical assessment form of patient identity, triage type, response time, primary survey (using $\mathrm{ABCDE}$ method) and secondary survey include: medical history, physical examination, other assessment ( assessment of pain and falling risk), conclusions when ending treatment, 
patient condition upon discharge, follow-up instruction and physician authentication.

\section{Identifying User Needs Based on Physical, Anatomical and Content Aspects of the Emergency Nursing Form}

Need Identification in emergency nursing assessment form RSD Balung Jember was conducted using interview technique with user in which nurse and medical recorder work as form designer.

\section{Physical Aspects}

Based on the results of interviews with the respondents obtained the result that the desired ink for the form is black ink, the type and size of paper used is A4 paper weighing 80 grams. The paper is white in accordance with the color of the ink form so as to produce a clear text.

\section{Aspects of Anatomy}

Based on the results of interviews with the respondents obtained the results that the head of the form (heading) is not much different from the initial medical assessment form, the title of the form is on the top left with the head of the form, so that the right side can be used for patient identity. The introduction of the title used for the new form is an emergency nursing assessment in accordance with the purpose of the form. The space used to design the new form is $1.15^{6,11,24}$. Requires nurse's authentication space as accountability to service.

\section{Aspects of Content}

Based on interviews, most nurses and medical recorders state that the minimal content of the nursing assessment form is social identity, disease history, triage type, allergy history, primary and secondary surveys, fall risk, pain scale, nursing evaluation, follow-up, tasks abundant and authentic nurses responsible for the service.

The nursing documentation review format includes the date of MRS, assessment by the patient's social identity, identity of the person responsible, medical history, health function pattern, physical examination, diagnostic examination, laboratory examination, and therapy. ${ }^{25}$

Based on the standard of the hospital emergency nursing level III form of Baladhika Husada Jember that the contents of form include major complaints, disease history, primary survey (airway: free, gargling, wheezing, ronchi, stridor, snoring, incubated, breathing: spontaneous; tachipneu; dispneu mechanical ventilation, ventilator wear, respiratory, circulation: tension, CRT, skin color, hemorrhage, skin turgor, disability: response pupil light reflex and awareness level), secondary survey (anatomy diagram, pain, abrasion, lacerations, contusions, burns, bites, puncturing, vulnus apertum, ptichiae, weight, height, pain scale), assessment, nursing diagnosis, nursing plans / actions, hours and evaluations, abundant tasks, authentication of 1 , responsible for nurse authentication.

The contents of the emergency nursing assessment form RSD Balung Jember are patient identity, triage type, date and time of entry of IGD, history, history of allergy, primary survey (Airways: free; gargling; wheezing; ronchi; stridor; snoring; intubation; Breathing: spontaneous; tachipneu; dyspneu; ventilator; bagging; circulatory: pulse; CRT; bleeding; skin; disability; awareness; response; pupils; light reflex); secondary surveys (anatomy diagram, scale of pain), nursing diagnoses, action plans, independent nursing actions, collaborative actions, nursing evaluation, follow-up, abundant tasks and nurse authentication.

\section{The Design of Initial Medical and Emergency Assessment Form}

\section{Physical Aspects}

Based on observations and interviews with the respondents, researchers designed the form using A4 type 80 gram paper and $21 \mathrm{~cm} \times 29.7 \mathrm{~cm}$ paper size on a new preliminary medical assessment form.

\section{Aspects of Anatomy}

Based on the observation and interviews to the respondents, the researcher uses the name and complete address of the health facility that is Balung Local Hospital Jl. Rambipuji No. 9 Balung Jember Zip Code. 68161 Tel. (0336) 621017, 621595 Fax. 0336-623877 as well as the title of a new emergency medical emergency initial assessment form. This introductory section explains the purpose of the form and sometimes the purpose is also indicated by the title so that the title the researcher uses for the new form is the initial medical assessment of the emergency department.

The instructions section on the new emergency medical emergency assessment form is not much different from the previous one, but in the circle instruction one + /becomes * circle the appropriate item and mark $\sqrt{ }$ on $\mathrm{m}$ need on the new form. A command directive is used to state how to fill out a form. Boundary edge of the initial emergency medical assessment form made by researchers 
in accordance with the existing theory of upper and lower limits $0.64 \mathrm{~cm}$, left border $1.76 \mathrm{~cm}$, right border $0.76 \mathrm{~cm}$. The type of letters used by researchers in designing the initial emergency medical assessment form is Arial typeface. The form cover provides space for the signature and the bright name of the doctor on duty.

\section{Aspects of Content}

The item in the initial emergency medical assessment consist of: patient identity, arrival time, patient payout, case type, triage symbol, incoming patient, communication mode, primary survey with $\mathrm{ABCDE}$ method, vital signs, anthropometry, pain scale , anamnesis, RPD, RPS, RPK, drug reconciliation, fall risk, functional, physical examination, anatomy diagram, occupational diagnosis, action plan and evaluation, follow up and final condition of patient.

The grouping of preliminary medical emergency assessment data forms includes:

1) Hospital Identity Group

2) Identity Form Group

3) Patient Identity Group

4) Triage Identification Group

5) Primary survey group

6) Secondary survey group

7) Closing group

Sorting items based on predefined data groups i.e. hospital identity group, form identity group, patient identity group, triage identification group, primary survey group (ABCDE, vital signs, anthropometry, pain assessment), secondary survey (medical history, drug reconciliation , falling risk, functional, physical examination, anatomical diagram, work diagnosis, action plan and evaluation, follow up, patient end condition), cover group.

The method of filling in the new form is manually filled by the physician who cares for the patient at the ER with the help of the Form Filling Technical Instructions.

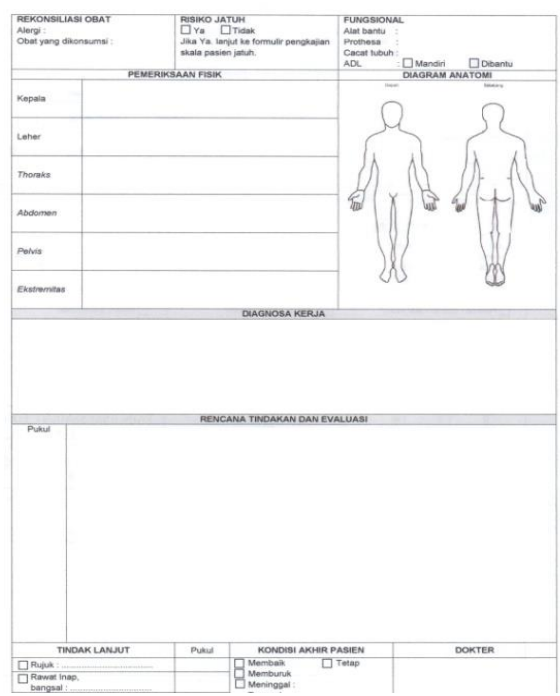

Figure 1. Design of Initial Medical Form (Part 2)

\section{The Design of Emergency Nursing}

\section{Assessment Form}

The design of an emergency nursing assessment form aimed at describing the form expected by the user. The process of designing a new emergency nursing assessment form is carried out according to user requirements and standards set by KARS version 2012. According to respondents it is good that nursing assessment is made in the form of application so as to facilitate the nurse in determining nursing diagnosis.

\section{Physical Aspects}

Based on the observations and interviews with respondents in designing emergency nursing assessment form is black ink. Type A4 paper is weighing 80 grams, paper size $21 \mathrm{~cm} \times 29.7 \mathrm{~cm}$. The color of white paper matches the contrast of ink colors.

\section{Aspects of Anatomy}

Based on observations and interviews to the respondents, the head of the form used in the emergency nursing assessment form is Balung Regional Hospital $\mathrm{Jl}$. Rambipuji No. 9 Balung Jember Zip Code. 68161 Tel. (0336) 621017, 621595 Fax. 0336-623877. The title used on the new form is an emergency nursing assessment. The directive of the instructions made by the researcher is the same as in the initial emergency medical assessment form. The type of letters that researchers use in the form design is Arial in accordance with the wishes of the user. The researcher makes a cover section of the form used to include the bright name and signature of the caring nurse.

\section{Aspects of Content}

The distribution of items on the emergency nursing assessment form has been in accordance with the needs of users and standards. The items in the emergency nursing assessment consist of: patient identity, arrival time, allergy history, primary survey with ABCDE method, vital signs, anthropometry, anatomy diagram, fall risk, pain scale, nursing diagnosis, action plan, independent nursing actions, collaborative acts, supportive actions, heart actions, ENT / eye actions, obstetrical actions, nursing evaluation, followup, end conditions, and limbs.

Grouping of emergency nursing assessment form data includes:

1) Hospital identity Group 
2) Identity form Group

3) Pstient identities Group

4) Re-triage identification Group

5) Health history Group

6) Primary survey group

7) Secondary survey group
8) Closing group

Sorting items based on predefined data sets. The manner of filling in the new form is manually filled by the nurse who cares for the patient at the ER within the Form Feeding Technical Instructions.

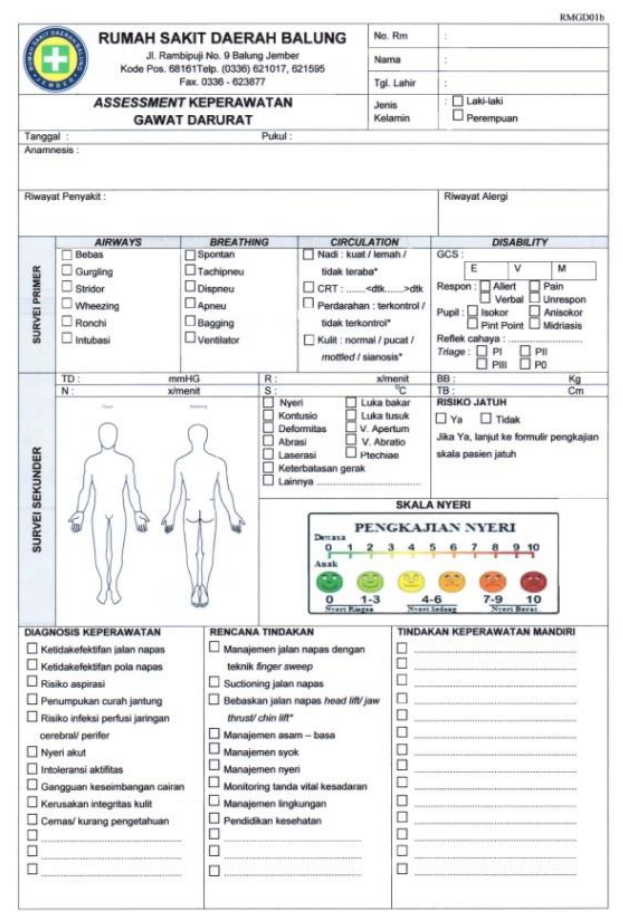

Figure 2. Design of Emergency Nursing Assessment Form (Part 1)

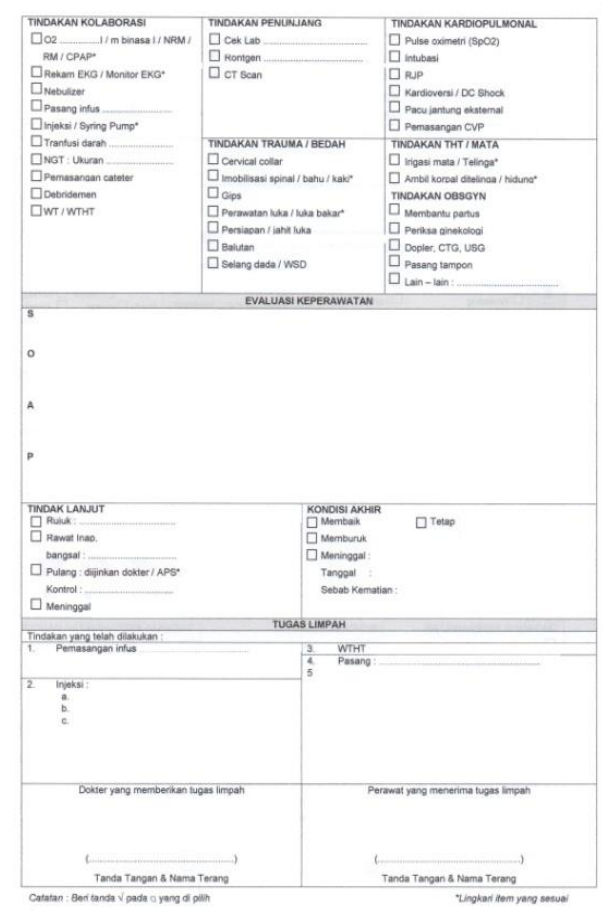

Figure 3. Design of Emergency Nursing Assessment Form (Part 2) 


\section{CONCLUSION}

Physical aspect of new emergency form using A4 type 80 gram paper and paper size $21 \mathrm{~cm} \times 29,7 \mathrm{~cm}$. The anatomical aspect of the initial emergency medical assessment form should include patient identity information, triage type, primary survey and secondary surveys, other assessments (assessment of pain and fall risk), and physician authentication whereas in the minimal contents aspect of the emergency nursing assessment form, social history, disease history, triage type, allergy history, primary and secondary surveys, fall risk, pain scale, nursing evaluation, follow-up, abundance and nurse authentication responsible for service.

\section{REFERENCE}

1. Arfah, 2016. Analisa Desain Formulir Assessment Awal Pasien Rawat Jalan di RSUD dr. H. Soewondo Kendal Tahun 2016. internet bersumber dari http://eprints.dinus.ac.id/21416/1/abstrak_19157.pdf/ diakses pada Senin 20 Nopember 2017 pukul 18:21.

2. Arifiana, 2014. Analize Design of Admission and Discharge Summary's Form (RM.1) in RSUD Kajen, Pekalongan. internet bersumber dari https://www.scribd.com/doc/313987922/ANALISISDESAIN-FORMULIR-RINGKASAN-MASUK-

KELUAR-pdf/diakses pada Senin 20 Nopember 2017 pukul 17:12.

3. Stephanie K. Mueller, MD; Kelly Cunningham Sponsler, MD; Sunil Kripalani, MD, MSc; Jeffrey L. Schnipper, MD, MPH. 2012. Hospital-Based Medication Reconciliation Practices. American Medical Association. ARCH INTERN MED/VOL 172 (NO. 14), JULY 23, 2012.

4. P. Beraldi, M.E. Bruni, D. Conforti. 2002. Designing robust emergency medical service via stochastic programming. European Journal of Operational Research 158 (2004) 183-193.

5. Lina M Hellstrom, Asa Bondesson, Peter Hoglund and Tommy Eriksson. 2012. Errors in medication history at hospital admission: prevalence and predicting factors. Hellstrom et al. BMC Clinical Pharmacology 2012, 12:9. http://www.biomedcentral.com/1472-6904/12/9.

6. Arifiyanti, 2012. Analisa Desain Formulir Resume Asuhan Keperawatan RSJD dr. Amino Gondhoutomo Periode 2012. internet bersumber dari http://eprints.dinus.ac.id/7717/1/abstrak_10690.pdf/di akses pada Senin 20 Nopember 2017 pukul 18:34.
7. Astriani, 2012. Analisis Desain Formulir Lembar Masuk dan Keluar (RM 02.1A) RS Hermina Pandanaran Semarang. internet bersumber dari http://eprints.dinus.ac.id/7705/1/abstrak_10940.pdf/di akses pada Senin 20 Nopember 2017 pukul 18:32.

8. Depkes RI. (2006). Pedoman Penyelenggaraan dan Prosedur Rekam Medis Rumah Sakit di Indonesia (Revisi II). Jakarta : Direktorat Jenderal Bina Upaya Pelayanan Medik.

9. --------- (2014). Peraturan Menteri Kesehatan Republik Indonesia Nomor 56 Tahun 2014 tentang Klasifikasi dan Perijinan Rumah Sakit. Jakarta : Departemen Kesehatan RI.

10. Hatta, G. R. (2014). Pedoman Manajemen Informasi Kesehatan Disarana Pelayanan Kesehatan. (G. R. Hatta, Ed.) Revisi III. Jakarta: Penerbit Universitas Indonesia (UI-Press).

11. Hanik, 2011. Analisis Desain Formulir Laporan Operasi (RM 16) di Rumah Sakit Umum Daerah Kabupaten Karanganyar. internet bersumber dari https://ejurnal.stikesmhk.ac.id/index.php/rm/article/vi ew/64/diakses pada Senin 20 Nopember 2017 pukul $15: 42$.

12. Haq, A. A. (2015). Evaluasi dan Desain Formulir Ringkasan Masuk dan Keluar di Klinik Rawat Inap dr. M Suherman Universitas Muhammadiyah Jember. Politeknik Negeri Jember.

13. Huffman, Edna K. (1999). Health Information Management. Translate Ekardius. (R. Jennifer Cofer, Ed.).

14. Kemendagri RI. (2009). Undang-Undang Republik Indonesia Nomor 44 Tahun 2009 tentang Rumah Sakit. Jakarta : Departemen Kesehatan RI.

15. Lubis, 2017. Analisis Desain Formulir Persetujuan Tindakan Medis di Rumah Sakit Umum Madani Medan Tahun 2017. internet bersumber dari http://www.jurnal.kampusimelda.ac.id/index.php/jfk/ article/view/188/ diakses pada Senin 20 Nopember 2017 pukul 17:09.

16. Maharani, 2013. Analisis Desain Formulir Lembar Masuk dan Keluar Rawat Inap (RM1) di Rumah Sakit Umum Kota Semarang Tahun 2013. internet bersumber dari http://eprints.dinus.ac.id/7842/1/jurnal_12705.pdf/dia kses pada Senin 20 Nopember 2017 pukul 15:28.

17. Masrochah, 2017. Analisis Desain Formulir Resume Medis di RSUD Kota Salatiga, Jurnal Manajemen Informasi Kesehatan Indonesia, vol. 5, no.1, pp.6062. 
18. Menkes RI. (2009). Keputusan Menteri Kesehatan Republik Indonesia Nomor 856 Tahun 2009 tentang Instalasi Gawat Darurat.

19. Menkes RI. (2008). Peraturan Menteri Kesehatan RI Nomor 269/MENKES/PER/III/2008.

20. Naufala, 2014. Analisis Desain Formulir Resume Keperawatan (RM 9) di Rumah Sakit Panti Wilasa dr. Cipto Semarang Tahun 2014. internet bersumber dari https://slideus.org/analsis-desain-form-resume-

keperawatan/diakses pada Senin 20 Nopember 2017 pukul 17:22.

21. Pamungkas, 2012. Analisis Desain Formulir Lembar Masuk dan Keluar RM 1 di RS Mardi Rahayu Kudus. internet bersumber dari http://eprints.dinus.ac.id/7683/1/abstrak_10469.pdf/ diakses pada Senin 20 Nopember 2017 pukul 18:28.

22. Peraturan Menteri Kesehatan RI Nomor 012 Tahun 2012 tentang Akreditasi Rumah Sakit.

23. Pratiwi, 2015. Analisis dan Perancangan Desain Formulir Edukasi Terintegritas Pasien Rawat Inap di RSUD kota Semarang. internet bersumber dari http://eprints.dinus.ac.id/17393/jurnal_16012.pdf/diak ses pada hari Rabu 11 Januari 2017 pukul 10:57.

24. Purnomo, 2014. Analisis Desain Formulir Lembar Masuk dan Keluar Rumah Sakit Roemani Muhammadiyah Semarang. internet bersumber dari http://eprints.dinus.ac.id/14012/1/AGUNG_PURNO MO.pdf/ diakses pada Senin 20 Nopember 2017 pukul 18:26.

25. Puspitasari E, 2017. Perancangan Desain Formulir Rekam Medis Pasien Rawat Jalan Poliklinik Umum di Puskesmas Kauman Kabupaten Ponorogo, Global Health Science, vol.2, no. 2, pp.155-164.

26. Putranto, 2012. Analisis Desain Formulir Laporan Operasi (RM22) di Rumah Sakit Bhakti Wira Tamtama Semarang Tahun 2012. internet bersumber dari

http://eprints.dinus.ac.id/7716/1/abstrak_10691.pdf/di akses pada Senin 20 Nopember 2017 pukul 18:23.

27. Qomariyah, 2012. Analisa Desain Formulir Resume Keperawtan Pasien Pulang / Meninggal di RS Bhayangkara Semarang. internet bersumber dari http://eprints.dinus.ac.id/7693/1/abstrak_10949.pdf/di akses pada Senin 20 Nopember 2017 pukul 18:36.

28. Saputra, 2013. Analisis Desain Formulir Lembar Masuk dan Keluar RSIA Gunung Sawo Semarang Tahun 2013. internet bersumber dari http://mahasiswa.dinus.ac.id/docs/skripsi/jurnal/1267 6.pdf/diakses pada Senin 20 Nopember 2017 pukul
15:33.

29. Whardani, D. R. (2015). Evaluasi dan Perancangan Formulir Pendaftaran Rawat Jalan Pasien Baru di RSU Hai Surabaya. Jember. Politeknik Negeri Jember. 